\title{
Comparative Studies on the Phytochemical Properties of Tumeric (Curcuma longa) and Ginger (Zingiberofficinale Roscoe)
}

\author{
Ifeoma Perpetua Oragwu ${ }^{1}$, Nkechi Perpetua Maduekwe ${ }^{2}$ \\ ${ }^{1}$ Department of Pure and Industrial Chemistry, Chukwuemeka Odumegwu Ojukwu . Unversity, Uli, Anambra State, Nigeria \\ ${ }^{2}$ Departments of Medical Microbiology, Azikiwe University Teaching Hospital, Nnewi, Anambra, Nigeria
}

\begin{abstract}
Turmeric (Curcuma longa) and Ginger (Zingiber officinale Roscoe) rhizomes, both from Zingiberaceae family, had been studied for their physico/phytochemical and bioactive compositions, as a natural source of anti-microbial drugs. The active ingredients in turmeric and ginger were isolated using different solvents, such as, chloroform, ethanol, hexane and benzene, while rotary evaporator was used to separate the moisture contents, which were 12.38 and $11.15 \%$ for both tumeric and ginger respectively. Ash contents were $7.45 \%$ and $7.20 \%$, while, specific gravity were $0.34 \%$ and $0.25 \%$ for both tumeric and ginger respectively. Coumarin, the major content of tumeric was identified in all the solvent extracts, while, polyphenol was presence in ginger extracts. Saponin, terpenoids, and anthocynins, were found to be present in all the solvent extracts of both turmeric and ginger. Carbohydrates, protein and alkaloid contents were tested using standard methods. Protein was identified in turmeric extract, but, not in ginger. The phyto-chemicals and bioactive compositions of tumeric and ginger have proved them source materials for drug formulations and antimicrobial agents, to fight against some pathogens and maintain some health challenges.
\end{abstract}

Keywords: Tumeric, ginger, phyto-chemicals, anti-microbial, solvent-extraction.

\section{INTRODUCTION}

$\mathrm{R}$ ecently, there is renewed scientific interest in investigation, isolation, identification and characterization of plants' bio-active chemicals, to combat disease causing pathogens that had proved resistance to already existing drugs, (Ali, 2008). Hence, researches and innovations on new anti-microbial agents from natural origins are of paramount importance. Formulation and development of unharnessed herbal concoctions, as a means of synthesizing new and improved antimicrobial pharmaceutical products is the major target of this research work. Studies had shown that the rate of resistance of microbes to already existing drugs and increased adulterated ones in our health systems had imposed great threat to human health. It had been expected that some phytochemical compounds from natural sources could be extracted, processed and used in the formulation of drugs for most allopathic or orthodox health treatments. It had been observed that many people from developing countries prefer natural medicine to orthodox ones, due to their affordability, packaging, availability, lack of side-effect, etc.
(Osemene,2011) and (Veeresham, 2012), reported that pharmacologically active plant extracts can interact with conventional drugs, because, they may provide an increased dose for similar compounds. He also stated that, some phytochemicals can interfere with the body system that metabolises drugs, making them to last longer in the body and have a more powerful cumulative effect. Natural products had been reported as infinite alternative sources for drug development, novel chemotypes, pharmacophores, and scaffolds for amplification into efficacious drugs for a multitude of disease indications or other valuable bioactive agents (Negi, et al ,1999).

Many phytochemicals from plants are directly or indirectly the backbone of traditional system of healing throughout the globe. World Health Organization had suggested that medicinal plants are the good source for variety of drugs can be used in treatment of some health issues (Swant and Godghate, 2013). Studies on the phytochemical compositions of some common herbs and plants had been preferred, due to their low cost, availability, and absence of side effects. A lot of reports had shown that natural products are playing great roles in modern drug development, especially for antibacterial and anti-tumour agents. A great number of plants' derivatives are important novel pharmacological active compounds to modern drug discovery and development, among which are Tumeric and Ginger. Some studies had shown that these plants have almost the same scientific classification, properties, anti-inflammatory and other therapeutic effects (Al-Suhaimi, et al, 2011).

Tumeric (Curcuma longa) and Ginger (Zingiber officinale Roscoe) are perennial rhizomes (root) of Zingiberaceae family, which are commonly used as spices, flavouring agents and for traditional medicine in many developing countries. (Kanjilal et al, 2002) and (Dixit et al, 2002) examined and characterized the morphological and chemical properties of tumeric. Curcumin, which is a natural phenol, had been reported as the major compound responsible for tumeric's bright yellow colour, (Dixit et al, 2002). Negi, et al (1999) isolated the yellow pigment from turmeric oleoresin and discovered the antibacterial activities against Bacillus aerus, Bacillus coagulus, Staphylococcus aureus, Eschericha coli and Pseudomans aeruinosa. (Sanatombi R. and 
Sanatombi, K. 2017) studied on the nutritional and bioactivity values of plants belonging to Curcuma genus and provided future perspectives for more research on the pharmaceutical applications for turmeric plants. Different species of tumeric had been discovered which are important for selection of genotype with higher yield and better quality.

Chemical analysis of ginger shows that it contains over 400 different compounds, (Demin, and Yingying, 2010). The major constituents in ginger rhizomes are carbohydrates, and phenolic compounds, according to the studies of (Park and Song, 2014).

Ginger, which is a source of valuable phytonutrients, characterized by its aromatic odour and pungent taste. Researches had indicated that ginger and tumeric are effective in reducing inflammation in arthritic condition. (Neeru, et al 2013) reported extensively on the origin of ginger, cultivation, application in traditional medicine, in decorative, as antipoisoning agent, reduction of cholesterol, block excessive blood clothing, and fight against arthritis. Ginger rhizome may be used as digestive aid, anti-nausea remedy, control to baldness, reduce toothache, snake bite, help new born mothers cleanse their womb after child-birth, etc. The composition of ginger varies with the type, agronomic conditions, curing methods, drying and storage conditions (Rehman et al, 2011).

The major aim of this research is to isolate some phytochemical and physico-chemical compositions of turmeric and ginger rhizomes. Also, to compare their medicinal and therapeutic applications into some orthodox medicines. This innovation could help in formulation of some new antimicrobial agents to combat the resistance of some disease causing micro-organisms.

\section{MATERIALS AND METHODS}

\subsection{Materials}

Some chemicals, reagents and materials used in this research work includes: Ethanol, methanol, hexane, and chloroform were gotten from ONEGOD Chemical Store, Bridge Head Market, Onitsha, Anambra State, Nigeria. Tumeric and Ginger rihzomes were bought from Afor Egbu, Market, Ihiala.

\subsection{Preparation of Samples}

Fresh rhizomes of ginger and turmeric were thoroughly washed separately, skinned, chopped into pieces, allowed to dry using an electric oven set at $45{ }^{\circ} \mathrm{C}$, and weighed at intervals, until constant weights were achieved. $1000 \mathrm{~g}$ of each samples was ground into powder after cooling, using an electric grinding machine and stored in two dry sample bottles for further analysis.

\subsection{Physico-chemical Analysis}

The specific gravity, moisture content and percentage ash content were carried out on turmeric and ginger rhizomes according to standard. The parameters were calculated respectively using the formula below:

$$
\begin{array}{rlll}
\text { i. } & \text { Density }\left(\mathrm{g} / \mathrm{cm}^{3}\right) & = & \frac{\text { Weight of sample }(\mathrm{g})}{\text { Volume }(\mathrm{cm})} \\
\text { ii. } & \text { Moisture Content } \%= & \frac{W 2-W 1}{W 3-W 2} \times 100 \\
\text { iii. } & \text { Ash Content } \% & = & \frac{W 2-W 1}{W 3-W 2} \times 100
\end{array}
$$

\subsection{Phytochemical Analysis of Tumeric and Ginger}

\section{i. Sample preparation}

$100 \mathrm{~g}$ of both turmeric and ginger rhizome powder were each soaked in $100 \mathrm{ml}$ of ethanol, methanol, hexane and chloroform respectively. These were left for $72 \mathrm{hrs}$ and were shaken at $2 \mathrm{hrs}$ intervals, using a shaking orbit machine. The mixture was filtered through a $0.45 \mu \mathrm{m}$ nylon membrane filter. The extracts were evaporated to dryness under reduced pressure at $40^{\circ} \mathrm{C}$ by a rotary evaporator. Each test sample of turmeric or ginger was labelled as TC (tumeric in chloroform); TE( turmeric in ethanol); $\mathrm{TH}$ (turmeric in hexane) and $\mathrm{TM}$ (turmeric in methanol) / GC(ginger in chloroform); GE (ginger in ethanol); GH (ginger in hexane) and $\mathrm{GM}$ ( ginger in methanol), according to the solvent used in the extraction process. The phyto-chemical compositions of turmeric and ginger were each determined according to the standards of Amir et al., (2005), Sadeo and Amit (2015), and Arawande et al., (2013).

\section{i. Carbohydrate Content Using Benetict's Test}

$2 \mathrm{mls}$ of Benedict's reagent was added to $1 \mathrm{ml}$ of the extract and boiled for 3 minutes. A reddish brown precipitate indicates the presence of carbohydrate (Reducing sugar). Reducing sugars are oxidized by the copper ion in solution to form a carboxylic acid and a reddish precipitate of copper (I) oxide.

\section{ii. Protein and Amino Acids( Biurret Test)}

$1 \% \mathrm{NaOH}$ (Sodium hydroxide) solution was added to $1 \mathrm{ml}$ of sample extract, followed by few drops of aqueous $1 \%$ Copper (II) sulphate solution. The appearance a purple solution indicates the presence of protein.

\section{iii. Presence of Alkaloid (Mayer's Test) Test for alkaloids}

$3 \mathrm{ml}$ of $2 \% \mathrm{HCl}$ was added to $1 \mathrm{ml}$ of turmeric and ginger solvent extracts. These mixtures were treated with few drops of Mayer's reagent (Potassium Mercuric iodine Solution) in different test tubes. Formation of a creamy white precipitate indicates presence of alkaloids.

\section{iv. (a)Presence of Tannins by Bromine water test}

$2 \mathrm{mls}$ 0f bromine water was added to $1 \mathrm{ml}$ each of samples of turmeric and ginger extracted in different solvents. Decoloration of the bromine water, indicated the presence of tannins.

\section{(b) Presence of Tannins using Ferric Chloride test}

Few drops of $1 \%$ ferric chloride solution was added to each sample extracts from the three solvents, brownish- green or blue- black colouration confirmed the presence of tannins. 


\section{v. Presence of Phenol using $10 \% \mathrm{FeCI}_{3}$}

1o $\%$ of Ferric solution was prepared and diluted with 0.1 m0ls. of $\mathrm{NaOH}$ solution, drop by drop until a permanent brown colour appeared. This solution was filtered and the filtrate used for the phenol test. I $\mathrm{ml}$ of the ferric solution was added into $5 \mathrm{ml}$ of each sample extracts. Appearance of fresh bluish- black color indicates the presence of polyphenols.

\section{vi. Test for Flavonoids ( Shinoda Test)Zinc - HCI reduction Test}

A piece of magnesium ribbon was added in $\mathrm{Conc} . \mathrm{HCl}$ and mixed with $2 \mathrm{mls}$ of of the samples. Formation of a pink colour after few minutes indicates presence of flavonoids.

\section{vii.Presence of Terpenes, Triterpenoids or Terpenoids( Salkowski Test)}

$2 \mathrm{mls}$ of chloroform and $3 \mathrm{mls}$ of Con. $\mathrm{H}_{2} \mathrm{SO}_{4}$ were added to each of the extracts. Formation of a yellow ring at the interface of the two liquids which turns reddish brown colour later, shows presence of triterpenoids or terpenoid.

\section{viii. Test for Flavonoids}

$3 \mathrm{ml}$ of dilute ammonia was added to $2 \mathrm{ml}$ of each plant's extracts, followed by addition of $1 \mathrm{ml}$ of Conc. $\mathrm{H}_{2} \mathrm{SO}_{4}$. A yellow coloration indicates the presence of flavonoids.

\section{ix. Test for Steroids Steroid}

$2 \mathrm{mls}$ of chloroform and Conc. $\mathrm{H}_{2} \mathrm{SO}_{4}$ were added to $1 \mathrm{ml}$ of solvent extracts of turmeric and ginger. Few drops of acetic acids were later mixed into the solution. Formation of greenish red coloration indicates the presence of steroids

\section{x. Presence Saponin Using Foam Test}

$2 \mathrm{ml}$ of each plant extract was mixed with $5.0 \mathrm{ml}$ of distill water and shake vigorously for a stable frothing. Few drops of saturated oil (olive oil) were added to each mixture and shake very well. Appearance of emulsion (foam) after shaking indicates presence of Saponins.

\section{xi Test for Phlobatannin}

$1 \mathrm{ml}$ of each extract was boiled with $1 \%$ hydrochloric acid. Formation of red precipitate indicates the presence of phlobatannin

\section{xii. Glycosides Determination Using Libermann's Test}

To each extract, $2 \mathrm{ml}$ of chloroform and concentrated acetic acid was added in an ice bath. Then 2 drops of concentrated $\mathrm{H}_{2} \mathrm{SO}_{4}$ was added. Formation of violent to the green colour indicates presence of glycoside.

\section{Xiii. $\quad$ Fixed Oil Using Paper/Spot Test}

Drops of each concentrated extract were added separately in between two filter papers and kept undistributed. Oil stain on each paper indicates presence of oils and fats xiv. $\quad$ Volatile Oil

$0.5 \mathrm{~g}$ of each extract was mixed with $1 \mathrm{ml}$ of $0.1 \mathrm{M} \mathrm{NaOH}$ solution and $1 \%$ aqueous $\mathrm{HCl}$. Formation of white precipitate indicates presence of volatile oil.

xix. Amino acid

$1 \mathrm{ml}$ of the sample extracts was each transferred into a test tube and $0.5 \mathrm{ml}$ ninhydrin, was add on it and boil for $5 \mathrm{mins}$. Formation of a purple color indicates the presence of amino acid.

\section{xx. $\quad$ Protein Contents Using Biurret Test}

$1 \% \mathrm{NaOH}$ (Sodium hydroxide) solution was added to the sample extract, followed by few drops of aqueous $1 \%$ Copper (II) Sulphate solution. The appearance a purple solution indicates the presence of protein

\section{xxi. Test for Starch}

$1 \mathrm{ml}$ of each extract was placed in a test tube and 3 drops of iodine solution added, a deep blue or blue black colour shows presence of starch.

\section{xxii. Monosaccarides}

$2 \mathrm{ml}$ of each extract was placed in a test tube and $2 \mathrm{ml}$ of barfoed reagent added. Brick red or brown precipitate or brown shows that monosaccarides is presence.

\section{xxii. Conmarin}

Evaporate $5 \mathrm{ml}$ of ethanoic solution, dissolve the residue in 1$2 \mathrm{mls}$ at hot distilled water and divide the volume into two parts intense fluorescence indicate the presence of conmarin.

\section{RESULTS AND DISCUSSIONS}

The results of the physico-chemical values of tumeric and ginger rhizomes, gave the moisture content of $12.38 \%$ and $11.15 \%$ for turmeric and ginger respectively, as shown in Table 1. The ash content of $7.45 \%$ for turmeric and $7.20 \%$ of ginger, were within acceptable range for plants of same family.

Table 1: Results on Phyisco-chemical analysis of Tumeric and Ginger

\begin{tabular}{|c|c|c|}
\hline Parameters & Tumeric & Ginger \\
\hline $\begin{array}{c}\text { Moisture content } \\
(\%)\end{array}$ & 12.38 & 11.15 \\
\hline Ash content $(\%)$ & 7.45 & 7.20 \\
\hline Specific gravity & 0.34 & 0.25 \\
\hline
\end{tabular}

Results on the phytochemical screening of solvent-extracts of turmeric and ginger are represented on Table 2 and 3 respectively. It was observed that terpenoids, saponins, and anthocynins, were present in all the solvent (chloroform $\mathrm{C}$, ethanol $\mathrm{E}$, Hexane $\mathrm{H}$, and methanol $\mathrm{M}$ ) extracts of both turmeric and ginger. Carbohydrates/monosaccharide was identified at high concentration in all the solvent extracts, except for hexane in turmeric (TH) as in Table 2, and ethanol 
extract of ginger (GE). This high concentration of carbohydrate $\left(\mathrm{C}_{5} \mathrm{H}_{10} \mathrm{O}_{4}\right)$ shows, that the plants are photosynthetic in nature. The monosaccharide content of the plants are evidence that can polymerize to polysaccharides(sugar and glycogen), which are used for energy storage, ( Hainfield and Mertes ,2019) although, it is higher in turmeric than ginger.

Flavonoid was identified in all the solvent extracts of turmeric, except for hexane. In ginger, it was found in ethanol (GE) and methanol extracts (GM), but absent in chloroform (GC) and hexane extracts $(\mathrm{GH})$. The presence of flavonoids in turmeric and ginger is of great advantage for medicinal purposes. Many epidemiological studies had shown that the bio-availability, bio-activity, and metabolism of flavonoids depend on their configuration, number of hydroxyl groups and substitution of functional groups, (Shashank and Abhay, 2013). (Kelly, et al, 2002), also investigated on some health promoting effect of flavonoids and concluded that it is antiallergic, anti-cancerous, antioxidant, anti-inflammatory and anti-viral activities. Discoveries on flavonoids had resulted into reduction on cardiovascular mortality rate, according to (Panche, et al, 2016). There is scientific suggestions, that daily intake of red wine, which is rich in flavonoids can prevent the risk of heart diseases, reduce oxidation of lowdensity lipoprotein, and lower cholesterol level.

Steroids were identified in all the solvent extracts, except in hexane extract of turmeric (TH) and methanol extract of ginger (GM) as in Tables 2 and 3 respectively. Reports had shown that steroids can increase muscle cross-sectional area and mass, due to the increase in protein synthesis within the cell. (Husak and Irschick, 2009) had reported on the biochemical and cellular effects of steroids on the morphology of skeletal muscles and concluded that they can be translated into increased power and work during sports, such as in weight lifting. Tumeric and ginger had been proved as good sources of steroids, and can be extracted using chloroform or ethanol.

Alkaloids were identified in high concentration in ethanol, hexane and methanol extracts of ginger but low in turmeric. Alkaloids had been reported as class of naturally occurring amino-acids, derived from nitrogen-containing organic compounds and are secondary metabolites for biotic and abiotic activities according to (Taha, et al ,2009) and (Jiao et al, 2019). They are widely used in pharmacological formulations, such as, caffeine or nicotine, as stimulants, morphine or codeine, as analgesic or pain killer, quinine used as anti-malaria drugs, etc.

Protein is identified in all the turmeric extracts, except in hexane extract but it was absent in all the ginger extracts. This result had shown, that plant protein, which is highly preferable to animal protein could be derived from turmeric rhizomes, (Marcus, 2013).

Tannins and phenols were observed in ethanol and methanol extracts, but, were negative in chloroform and hexane extracts of both turmeric and ginger, as stated in Table 2 and 3 . Researches had considered tannins and phenols as good antioxidants, anti-inflammatory, anti-carcinogenic, antimutagenic, etc. Tannin had been proved to enhance glucose uptake, and are potential drugs for diabetic situation, according to (Kumari and Jain, 2012). Tannins, which are also poly-phenolic compounds had been reported to increase shelf life of some foods, accelerate blood clotting, reduce blood pressure, etc, (Chung et al,1998) and could be suggested suitable in drug formulations.

Terpenoids, saponins and anthocyanin were identified in all the solvent extracts of turmeric and ginger as shown in Tables 2 and 3. It has been reported that terpenoids are oxygenated derivatives of terpenes and are responsible for aromatic qualities in plants, according to (Rajesh and Anju 2014). They have been playing great role in traditional herbal remedies, and are under investigation for pharmaceutical functions.

Saponins, which are amphipatic glycosides, exhibit both hydrophilic (water-loving or polar) and lipophilic (fat-loving) properties, according to (Skene and Philip, 2006). Saponins can improve cardiovascular health issues, due to their ability to lower cholesterol level and body fats. Our findings had proved that ginger and turmeric are good source of saponin. (Ozlem and Giuseepa, 2007) also confirmed that saponin could lower cholesterol level, which are the major cause of heart disease, control chronic kidney disease, lower blood sugar level, and maintain body weight by suppressing appetite. (Bhandari et al,2005) observed a significant lipid lowering activity of ethanol extract of Zingiber officinale in diabetic rats, while, (Al- Amin et al, 2006) concluded that raw ginger possesses hypoglycaemic, hypocholesterolaemic and hypolipidaemic potential that reduces cholesterol level. (Tanabe, et al, 1993) isolated principle components from ginger and observed that they exhibited inhibitory effect on cholesterol biosynthesis. The anti-inflammatory properties of ginger as reported by (Afzal et al., 2001); (Grzanna et al., 2005), showed several lines of evidence in different animal models, and to a lesser extent in human cells.

Anthcyanins $\left(\mathrm{C}_{15} \mathrm{H}_{11} \mathrm{O}\right)$, are natural colourants consisting of aromatic rings bonded to a heterocyclic ring that contains oxygen, which is bonded to a carbon-carbon, to a third aromatic ring, found mainly in glycosides. (Araceli, et al 2009) referred to them as the most important pigment of the vascular plants responsible for the bright colour of fruits, roots, or vegetables. It is found in higher concentration in both turmeric and ginger extracts, as represented in Tables 2 and 3.

Glycoside was observed to be present in ethanol and hexane extracts of turmeric and ginger, evidence that it can be isolated using these solvents. They are secondary metabolites and studies had shown that they possess strong physiological effect in the heart muscles.

Coumarin $\left(\mathrm{C}_{9} \mathrm{H}_{6} \mathrm{O}_{2}\right)$, which is an aromatic compound consisting of fused benzene and an $\alpha$-pyrone ring, was 
observed in all the solvent extracts of turmeric, but, identified only in chloroform and hexane extracts of ginger, as in Table 3. Researches had shown that coumarin exhibits a lot of biological properties, which include anti-microbial, antiinflammatory, etc, according to (Rohini and Srikuma, 2014). (Venugopala, et al, 2013) worked extensively on some pharmacological properties of coumarin and discovered that it could be isolated, characterized, purified and be incorporated into some drug formulations, for treatment of some health challenges.

Carboxylic acid and amino acids were not identified in all the turmeric extracts, but, the former was observed sparingly in hexane extract of ginger $(\mathrm{GH})$ as in Table 3. This shows that both turmeric and ginger are not good source of organic acids.

Phlobatonin, is present in chloroform extracts of both tumeric and ginger, as in Table 2 and 3. This shows that chloroform is a suitable solvent for extraction of phlobatonin, which had been known by its wound healing, anti-inflammatory, and anti-oxidant properties.

Fixed oil was observed in all the extracts of turmeric and ginger, although, absent in methanol extract of ginger (GM) as shown in Table 3 . The presence of fixed oil shows that they are suitable for blending essential oils, which can be used in drugs, cosmetics or food industries.

Volatile oils were identified in ethanol and methanol extracts of turmeric (TE and TM) respectively, as shown in Table 2. It was observed only in ethanol extract of ginger (GE), as in Table 3.

They are essential oils and have remarkable medicinal and commercial values.

Table 2: Result on Phytochemicals In Turmeric Rhizomes

\begin{tabular}{|c|c|c|c|c|}
\hline Parameter & TC & TE & TH & TM \\
\hline Carbohydrate & ++ & ++ & - & ++ \\
\hline Alkaloids & - & - & + & + \\
\hline Flavonoids & + & + & - & ++ \\
\hline Steroids & ++ & + & - & + \\
\hline Amino acids & - & - & - & - \\
\hline Starch & - & - & - & - \\
\hline Monosaccharide & ++ & + & - & ++ \\
\hline Protein & + & ++ & - & + \\
\hline Tannins & - & ++ & - & ++ \\
\hline Phenols & - & ++ & - & ++ \\
\hline Terpenoids & ++ & + & ++ & + \\
\hline Saponins & ++ & + & ++ & + \\
\hline Glycosides & - & + & ++ & - \\
\hline Fixed Oil & ++ & + & ++ & + \\
\hline Volatile oil & - & ++ & - & + \\
\hline Phlobatonin & ++ & - & - & - \\
\hline & & & & \\
\hline
\end{tabular}

\begin{tabular}{|c|c|c|c|c|}
\hline Carboxylic acid & - & - & - & - \\
\hline Anthocynins & + & ++ & + & + \\
\hline Coumarins & + & ++ & + & ++ \\
\hline
\end{tabular}

Note: TC is Chloroform extract of (turmeric); TE is ethanol extract,; TH is hexane extract;

TM is methanol extract ; ++ is strongly positive; + is slightly positive and is negative.

Table 3: Result on Phytochemicals in Ginger Rhizomes

\begin{tabular}{|c|c|c|c|c|}
\hline Parameter & GC & GE & $\mathrm{GH}$ & GM \\
\hline Carbohydrate & + & - & + & + \\
\hline Alkaloids & - & ++ & + & + \\
\hline Flavonoids & - & + & - & + \\
\hline Steroids & + & + & + & - \\
\hline Amino acids & - & - & - & - \\
\hline Starch & - & - & - & - \\
\hline Monosaccharide & + & - & - & - \\
\hline Protein & - & - & - & - \\
\hline Tannins & - & + & - & + \\
\hline Phenols & - & + & - & + \\
\hline Terpenoids & + & ++ & + & ++ \\
\hline Saponins & ++ & + & ++ & + \\
\hline Glycosides & - & + & ++ & - \\
\hline Fixed Oil & ++ & + & + & - \\
\hline Volatile oil & - & + & - & - \\
\hline Phlobatonin & ++ & - & - & - \\
\hline Carboxylic acid & - & - & + & - \\
\hline Anthocynins & + & ++ & + & + \\
\hline Coumarins & + & - & + & - \\
\hline
\end{tabular}

Note: GC is Chloroform extract (ginger); GE is ethanol extract; GH is hexane extract;

GM is methanol extract; ++ is strongly positive; + is slightly positive; - is negative.

Tumeric and ginger rhizomes had been observed via our analytical mechanisms and results to be promising natural agent, in fighting aging and degenerative diseases. The use of different solvents in this research is to determine the most suitable for isolation of bioactive compositions of the rhizomes, because, extracts from same plant may have different medicinal or therapeutic applications.

\section{CONCLUSION}

There is an urgent need for evaluation of some herbal extracts from natural source, to substitute the already commercially produced antimicrobial agents, which has formed resistance to some diseases. The demand for unassessed natural products, with physico- and phyto-chemical compositions could result into more research on the best method of isolation, extraction, characterization, purifications, and application into pharmaceuticals, foods, or cosmetic formulations. The 
phytochemicals discovered in these plants could be suggested to pharmaceutical, cosmetics or food industries to be used for, as antimicrobial agents, antioxidants or additives.

The extractable phytochemicals from ginger and turmeric were observed to be a function of the solvents used. The overall assessment concludes that turmeric and ginger possess strong antibacterial, ant-thelmintic, anticancer, anti-parasitic, antiseptic, antioxidant, anti-inflammatory, anti-rheumatic, anti-tumor, anti-phlegmatic, antiviral properties. Further researches may be conducted by examining the anti-microbial activities of the solvent-extracts of ginger and turmeric so that the therapeutic usefulness of these extracts can be established.

\section{REFERNCES}

[1] Al-Suhaimi E . A. ; Al-Riziza, N. A.; Al-Essa, R. A.; (2011). Physiological and therapeutical roles of ginger and turmeric on endocrine functions. Journal of Chinese Medicine, vol. 39(2) 215231.

[2] Amitava, D., Kimberley, D. A. B. and Klein, M. D. (2014). Herbal and other Dietary Supplements that are Antioxidants, 295315.

[3] Ali, B.,H., Blunden, g., Tanura ,M.,O., and Nemmar, A.,(2008). Some Phytochemical, Pharmacological, and Toxicology Properties of Ginger (Zingerber Officinale Roscoe): A Review of Recent Research. Journal of Food and Toxicology, vol. 46(2), 409-420.

[4] Araceli, P.H. Lourdes, E., and A. R. Jose(2009). Chemical Studies of Anthocyanins: A Review" J. of Food Chemistry, vol.113 (4), 859-871.

[5] Arutselvi, R., Balasaravann, T., Ponmurugan, P. Muthn, N. and Suresh, P.(2012).

Phytochemical Screening and Comparative Study of Antimicrobial Activity of Leaves and Rhizomes of Tumeric Varieties. Asian Journal of Plant Science and Research, Vol. 2(2). 212-219.

[6] Ciddi V. (2012). Natural Products derived from Plants as source of Drugs. Journal of Advanced Pharmaceutical Technology \& Research, vol. 3(4), 200-201.

[7] Demin, G. and Yingying, Z.(2010). Comparative antibacterial activities of crude polysaccharides and flavonoids from Zingiber officinale and their extraction, American Journal of Tropical Medicine, vol. 5, 235-238.

[8] Dietr Macia, C.S., Luciana, G.S. Souza, D. A., Franisco, J.Q., Monte, Raimundo B. and Telma L.G. (2015). Chemical Composition of the Essential Oil and Fixed Oil Bauhinia Pentandra(Bong.), Pharmacognosy Magazine. 11(2), S362-S364.

[9] E. Al-Suhaimi, Al- Riziza, N. and R. Al-Essau(2011). Physiological and Therapeutical Roles of Ginger and Tumeric on Endocrine Functions". The American Journal of Chinese Medicine, 39, 215-231, 2011.

[10] Eleazu, C.O. and Eleazu K. C. (2012). Physico-chemical Properties of antioxidant Potentials of 6 New Varieties of ginger(Zingiber officinale). American Journal of Food Technology, 7(4), 241-221.

[11] Gaurav Kumar, Karthik Loganathan, Bhaskar Rao (2011). A Reviw on Pharmacological and Phytochemical Properties of Zingiber officinale Roscoe(Zingiberceae). Journal of Pharmacy Research, 4(9), 2963-2966.

[12] Hansfield, M. and Mertes, G.(2019). Treatment: Alpha Glucosidase Ihibitors. Encyclopedia of Endocrine Disease , (second edition), vol. 1, pp. 238-244.

[13] Husak, J. F. and Irschick, D. J.(2009). Steroids Uses and Human Performance: Lessons for Integrative Biologists. Journal of Integrative and Comparative Biology, 49(4), 354-364.

[14] Jiao, P., Ting-Ting, Z., Xi-Li, Yue, Liang, Li-Jun Wang, YongCan, H., and Hai-Tao Xiao(2019). Plant derived Alkaloids. The Promising Disease - Modifying Agents, for Inflammatory Bowel Disease. Pharmacology. www.frontiersin.org.articles.
[15] Kelly, E.,H., Anthony, R., T. and Denis, J., B.(2002). Flavonoid antioxidants chemistry,metabolism and structure activity relationship. Journal of Nutritional Biochemistry, vol. 13, (10), 572-584.

[16] Kumari, J. (2012).Tannins: An Anti-nutrient with Positive Effect to Manage Diabetes. Research journal of Recent Sciences, vol. $1(12), 1-8$.

[17] Marcus, J. B., (2013). Protein Basics: Animal and Vegetable Proteins in Food and Health. Journal of Culinary Nutrition. www.sceincedirect.com

[18] Negi, P.S., Jayaprasha, G. K., Jagan Mohan Rao, L., and Sakariah , K. K. (1999). Antibacterial Activity of Tumeric Oil: By-product from Cumrcumin Manufacture. Journal of 7Agric. Food Chem.,47(10)4297-4300.

[19] Neeru, B., Mostata, I. W., Amanat, A., and Mohamed, M. E.(2013) Ginger: A functional herb. Nova Science Publishers, Inc., NY, USA, ISBN-978-1, pp.51-71.

[20] Osemene, K. . P., Elujobi, A. A. and Ilori , M. O.(2011). A Comparative Assessment of Herbal and Orthodox Medicine in Nigeria. Research Journal of Medical Sciences, vol. 5(5),280-285.

[21] Ozlem G. U. and Giuseepa, M.(2007). Saponin: Properties, Applications and Processing, Journal of Food Science and Nutrition 47(3), 231-258

[22] Park, G. and Song J. H. (2014). Anti-cancer activity of Ginger (Zingiber officinale) leaf through the expression of activating transcription factor 3 in human colorectal cancer cell. BMC Complementary and Alternative Medicine, vol. 14,(1) article 408.

[23] Panche A., Diwan, A., and Chandra, S.,(2016). Flavonoids: An Overview, Journal of Nutritional Sciences vol. 5. 16-41.

[24] Pant, M., Misra, H., Jain, D. C.(2013) Phytochemical Investigation of Ethyl Acetate Extract from Curcuma aromatica Salis. Rhizomes. Arabian J. Chem. 6, 279-283.

[25] Pawar, M. A. , Palil, S. S., and Nagrik, D. M. (2015). Phytochemical and Physiochemical Investigation of Curcuma Longa Linn Rhizome. International Journal of Chemical and Physical Sciences. Vol. 4, $458-463$.

[26] Rajesh. Y. and Anju, G., (2014). Chemistry of Terpenes, International Journal of Pharmaceutical Sciences Review and Research, 27(2)272-278.

[27] Rohini, K. and Srikuma, P. S. (2014). Therapeutic Role of Coumarin and Coumarin Related Compounds. Journal of Thermodynamics and Catalysis, vol. 5(2).

[28] Sawant, R. S. and Godghate, A. G. (2013). Qualitative Phytochemical Screening of Rhizomes of Curcuma Longa Linn. International Journal of Science, Environment and Technology, vol. 2(4) $634-641$.

[29] Sadeo P. and Amit K., T.(2015). Ginger and Its Constituents: Roles in Prevention and Treatment of Gastrointestinal Cancer. Journal of Gastroenterology Research, and Practice, vol. 5, 11.

[30] Shashank, K. and Abbay, K. P. ( 2013). Chemistry and Biological Activities of Flavonoids: An Overview. Hindawi Scientific World Journal vol. 2013, 16.

[31] Skene, C. and S. Philip (2006). Saponin-adjuvanted particulate vaccine for clinical uses. Research Methods 40(1),53-59.

[32] Sinha, K. K.(2003). Spices and Flavoring Crops/ Tubers and roots Encyclopedia of Food Sciences and Nutrition( Second Edition ) 239, (2003).

[33] Taha, H. S. ; EL-Bahr, H. K. and M.M. Seif-El- Nasr, M. M.(2009) "In vitro Studies on Egyptian Catharanthins Roseus $(L)$. Effect abiotic and abiotic stress on Indole Alkaloids Production. Journal of Applied Science Resource (15), 1826-1831.

[34] Venugopala, K. N., Rashimi, V., and Odhav. B.(2013). Review on Natural Coumarin Lead Compounds for their Pharmacological Activity.Journal of BioMed Research International, vol. 2013, 14.

[35] Yadava, N.,Sanatombi R., Sanatombi, K. (2017). Nutritional value, phytochemical composition, and Biological activities of edible Curcuma Species. : A Review.International J. of Food Properties, vol. 20(3), S2668-S2687. 